\title{
Perhelatan kenduri sko sebagai sebuah pesan kebudayaan masyarakat Kerinci di taman nasional Kerinci Seblat
}

\section{Cultural message of kenduri sko in the society of Kerinci Seblat National Park}

\author{
$\underline{\text { Asvic Helida }^{1}}$, Ervizal AM. Zuhud ${ }^{2}$, Hardjanto ${ }^{3}$, Y. Purwanto ${ }^{4}$, \& Agus Hikmat $^{2}$ \\ 1) Mahasiswa Pascasarjana S-3 Prodi KVT IPB \\ 2,5) Prodi KVT Institut Pertanian Bogor, ${ }^{3)}$ Prodi IPH Institut Pertanian Bogor \\ 4) Lembaga Ilmu Pengetahuan Indonesia (LIPI) \\ E-mail: asvic_helida@yahoo.com
}

\begin{abstract}
Kerinci society is indigenous tribe Indonesia inhabit Kerinci District, Jambi. They have various art and traditional ceremony that still exist until recent times. Kenduri sko is a form of customary prayer one that was held annually as an act of gratitude to God almighty for different harvest product. A message Kenduri sko an oral culture that has lasted hearts long time and hereditary. The cultural ceremony contains precious message such as integration, familiarity, awareness, togetherness and openness that become a fundamental factors to philosophy development to indigenous villagers in Kerinci. to reveal traditional ceremony Kenduri Sko of Kerinci as an oral tradition that has been occured for years and to deliver messages behind such tradition. The study was conducted in Dusun Baru Lempur Gunung Raya Sub District, Kerinci District in the month in October 2013 for 3 months. The approach used was conducted qualitatively by observation method through in-depth interviews with leaders of indigenous communities. there are cultural message that shows knowledge and natural resource utilization wisely and the realization to preserve natural resources.
\end{abstract}

Keywords: kenduri sko, culture messages, resources biodiversity, Kerinci, oral tradition

\begin{abstract}
Abstrak
Masyarakat Kerinci merupakan masyarakat asli Indonesia yang berdiam di Kabupaten Kerinci Provinsi Jambi. Mereka memiliki berbagai bentuk kesenian dan upacara perhelatan tradisional yang sampai sekarang masih dapat dijumpai. Kenduri sko adalah salah satu bentuk perhelatan adat yang diadakan setiap tahun sebagai wujud syukur kepada Tuhan Yang Maha Kuasa atas hasil panen yang diperoleh. Kenduri sko merupakan sebuah pesan kebudayaan lisan yang telah berlangsung dalam waktu yang lama dan turun temurun. Pesan yang memiliki makna keterpaduan, keakraban, kesadaran, kebersamaan dan keterbukaan yang menjadi pokok-pokok pembangunan dalam nagari menurut falsafah adat Kerinci. Penelitian ini bertujuan mengungkapkan upacara tradisional kenduri sko masyarakat Kerinci sebagai sebuah tradisi lisan yang telah berlangsung lama secara turun temurun dan mengungkapkan pesan-pesan kebudayaan yang terdapat di dalamnya. Penelitian dilakukan di Dusun Baru Lempur Kecamatan Gunung Raya Kabupaten Kerinci. Pendekatan penelitian dilakukan secara kualitatif dengan metode observasi partisipasi melalui wawancara mendalam dengan para tokoh masyarakat dan adat serta mengikuti kegiatan yang dilakukan masyarakat dalam tradisi tersebut. Hasil penelitian menunjukan terdapat pesanpesan kebudayaan yang menunjukan telah adanya pengetahuan akan pemanfaatan sumber daya alam biodiversitas secara bijak yang harus dilestarikan agar sumber daya tersebut tidak punah.
\end{abstract}

Kata kunci: kenduri sko, pesan kebudayaan, sumber daya biodiversitas, masyarakat Kerinci, tradisi lisan

\section{Pendahuluan}

Masyarakat Kerinci adalah salah satu masyarakat asli Indonesia yang berdiam di Kabupaten Kerinci Provinsi Jambi. Mereka berasal dari Hindia Belakang (Asia Tenggara) dan Mongolia, yang datangnya bersamaan dengan bangsa-bangsa yang menyebar ke seluruh pelosok nusantara pada abad ke tujuh (Zakaria 2012). Bahasa masyarakat Kerinci berbeda dengan bahasa daerah lainnya di Sumatera, namun 
masih berpokok kepada bahasa Melayu Tua (Austronesia) yang dituturkan dengan dialek Kerinci. Perbedaan ini disebabkan oleh letak daerah Kerinci yang terpencil sehingga mempunyai dialek tersendiri. Dialeknya berbeda dengan suku-suku Sumatera lainnya, namun pada umumnya mereka mengerti akan bahasa Melayu atau bahasa Indonesia. Karakteristik dari bahasa Kerinci juga tampak pada dialek yang banyak, setiap daerah memiliki dialek yang berbeda.

Kerinci juga memiliki aksara atau huruf sendiri yang disebut dengan aksara incung. Keberadaan aksara incung dapat ditemukan pada dokumen-dokumen lama masyarakat Kerinci. Aksara incung dibentuk oleh garis-garis lurus, patah terpancung dan melengkung namun garis lengkungan kita temui pada aksara tertentu dan jumlahnya hanya beberapa saja. Kemiringan garis-garis pembentuk huruf itu ratarata $45^{\circ}$, jadi bukan aksaranya yang ditulis miring seperti penulisan huruf latin yang ditulis miring bersambung. Aksara incung termasuk tulisan fonetik yang berjenis 'suku kata', semuanya merupakan bunyi huruf hidup seperti halnya dalam aksara Arab. Penulisan tanda bunyi untuk satu aksara incung di antaranya ditemukan 2 atau 3 macam, namun tidak sampai mempengaruhi pembentukan kata atau kalimat dalam sastra incung. Semuanya merupakan hasil kreasi yang tumbuh dari para pujangga Kerinci masa silam untuk mengangkat nilai-nilai estetis dalam khazanah kesusasteraan incung.

Masyarakat Kerinci memiliki berbagai upacara tradisional yaitu upacara kenduri sko, upacara asyeik, upacara ngasap negri, upacara mandi balimau, upacara mandi basantan, upacara tuhaun kayei, upacara ayun luci, upacara naik haji, gotong royong (turun ke sawah, negak rumah, menggali saluran air, menarik kayu). Semua upacara ini melibatkan banyak orang yang menandakan bahwa suku Kerinci memegang prinsip kesatuan dan persatuan yang kuat, saling membantu dan saling bahu membahu seperti pepatah mereka "kerjo kecik bertabur arai, kerjo gedang bertabur urai". Kebersamaan ini juga ditunjukan oleh pepatah 'sahalun suhak, salatuh bdei' memiliki makna kebersamaan dan hidup saling tolong menolong.

Kenduri sko adalah perhelatan paling besar bagi masyarakat Kerinci karena selain wujud syukur terhadap hasil panen yang diperoleh, bersamaan pada waktu kenduri sko juga dilaksanakan pengukuhan dan penobatan depati yaitu pimpinan adat tertinggi bagi masyarakat Kerinci. Kenduri sko merupakan pesan lisan kebudayaan masyarakat Kerinci yang dapat dimengerti dari istilah-istilah kognitif yang harus dipertimbangkan pada saat menafsirkannya bagi generasi selanjutnya (Vansina 1985).

Secara sederhana kebudayaan didefinisikan sebagai suatu hal yang bersifat umum dalam pikiran sekumpulan orang-orang tertentu yang mengacu kepada lingkungan masyarakat, memiliki banyak gagasan, nilai dan gambar yang sama, singkatnya mereka memiliki perwakilan yang bersifat kolektif pada diri mereka yang tidak dijumpai pada kumpulan orang lain. Kebudayaan secara umum memiliki sifat yang luas terutama dalam masyarakat berkebudayaan tertulis karena pada masyarakat berkebudayaan lisan orang hanya dapat menerima materi-materi yang bersifat kontemporer dan bersifat umum. Pada masyarakat berkebudayaan tertulis pengumpulan informasi bersifat selektif karena seseorang dapat mempelajari buku-buku atau naskah tua yang tidak dapat dipelajari semua orang.

Sebagai sebuah upacara kebudayaan, kenduri sko memiliki konsep-konsep dasar yang berhubungan dengan waktu, ruang, angka, realita dan penyebab. Kenduri sko dapat dikatakan sebagai sebuah kebudayaan lisan yang telah berlangsung antar generasi. Pewarisan kebudayaan kenduri sko terjadi karena transmisi dari orang tua ke anaknya (transmisi vertikal), dari rekan-rekan se-usia (transmisi horizontal) dan dari generasi yang lebih tua, bukan orang tua (transmisi obligue).

Vansina (1985) menyebutkan, agar tradisi lisan dapat dijadikan sebagai sumber sejarah yang secara ilmiah dapat dipertanggungjawabkan ada tiga hal penting yang harus dilakukan yaitu 1). Mendefinisikan dan mengkategorikan bukti lisan sebagai sumber sejarah sekaligus memberikan cara agar dapat digunakan untuk menulis buku sejarah; 2). Membahas hubungan praktis antara ilmu 
sejarah, antropologi sosial dan ilmu-ilmu relevan lainnya yang bermanfaat untuk mengumpulkan testimoni lisan dan 3). Menyiapkan justifikasi teoritis atas koleksi dan penggunaan bukti-bukti lisan dalam penulisan sejarah.

Berdasarkan hal tersebut di atas maka yang menjadi tujuan dari kajian ini adalah mendeskripsikan upacara kenduri sko yang dilaksanakan oleh masyarakat Kerinci dan mengungkapkan pesan-pesan kebudayaan yang terkandung di dalamnya.

\section{Metode Penelitian}

Penelitian dilakukan di Dusun Baru Lempur Kecamatan Gunung Raya Kabupaten Kerinci Provinsi Jambi selama 3 bulan (Oktober - Desember 2013). Metode penelitian bersifat kualitatif deskriptif dengan metode pendekatan desk study sejarah (studi dokumentasi) dan observasi partisipatif. Teknik pengumpulan data yang bersifat partisipatif terdiri dari wawancara bebas (open ended) dan wawancara mendalam (depth interview).

Wawancara dilakukan pada informan kunci (key informan) yaitu tokoh masyarakat yang terdiri dari ketua adat, kepala kampung dan kepala desa Dusun Baru Lempur serta anggota masyarakat yang dianggap mampu memberikan informasi yang akurat dengan kriteria tokoh masyarakat. Untuk mendapatkan informan kunci yang tepat didasarkan atas rekomendasi dari tokoh adat/tokoh masyarakat setempat atau disebut juga dengan metode snowballing yaitu teknik penentuan informan berdasarkan petunjuk atau penentuan informan awal terhadap seseorang yang dianggap lebih mampu memberikan informasi sesuai kebutuhan penelitian (Neuman 2006, Irawan 2006, Creswell 2009).

\section{Hasil Penelitian dan Pembahasan}

\section{Kerinci lebih dekat}

Yakin (1986) menyebutkan bahwa asal-usul nama Kerinci ada beberapa pendapat. Pendapat pertama menyebutkan bahwa seorang tokoh bernama Datuk Paduko Berhalo yang tinggal di tepi danau Kerinci (sekarang menjadi Desa Sanggaran Agung) kehilangan sebuah kunci yang jatuh ke dalam sungai dan bersusah payah akhirnya mendapatkan kembali kuncinya sehingga beliau menamakan sungai tersebut dengan Batang Kunci yang kemudian populer menjadi Batang Kerinci ("batang" bahasa daerah yang berarti sungai). Pendapat ke dua menyebutkan bahwa kerinci berasal dari bahasa Jawa "kering" dan "ci" yang berarti sungai kering, dari "keringci" kemudian berubah menjadi "kerinci". Pendapat ke tiga menyebutkan karena daerah Kerinci terletak pada dataran tinggi yang dilingkungi Bukit Barisan, di musim panas "kering" dan di musim hujan "cair" sehingga menjadi "kering cair" yang kemudian berubah menjadi "kerinci". Pendapat ke empat menyatakan bahwa sesuai dengan keadaan alamnya yang dipagari oleh bukit-bukit yang berderet dari utara ke selatan dengan puncak yang menjulang tinggi disertai dengan hutan yang lebat menyebabkan daerah ini sukar dilalui manusia sehingga menyebabkan daerah ini terkurung, keluar tidak bisa, masuk amat sulit seperti "terkunci", yang akhirnya menjadi kata "kerinci".

Kabupaten Kerinci disebut juga dengan "Sakti Alam Kerinci" merupakan daerah dataran tinggi dilingkungi oleh Bukit Barisan Selatan, terletak di sebelah barat Provinsi Jambi yang berjarak \pm 450 $\mathrm{km}$ dari ibukota propinsi, terletak di ketinggian 450 sampai dengan $1500 \mathrm{~m}$ di atas permukaan laut. Secara geografis terletak antara $101^{0} 08^{\prime}-101^{0} 50^{\prime}$ BT dan $1^{0} 41^{\prime}-2^{0} 26^{\prime}$ LS memiliki batas wilayah sebelah utara dengan Kabupaten Solok Provinsi Sumatera Barat, sebelah selatan dengan Kabupaten Sarko dan Kabupaten Bengkulu Utara Provinsi Bengkulu, sebelah timur dengan Kabupaten Bungo Tebo, sebelah barat dengan Kabupaten Pesisir Selatan Provinsi Sumatera Barat.

Kerinci merupakan daerah dengan karakteristik khas yakni merupakan daerah lembah dan perbukitan. Lembah Kerinci memiliki dataran luas berupa tanah endapan seluas $3808,50 \mathrm{~km}^{2}$ sehingga tampak seolah-olah Kerinci berada dalam sebuah "mangkok raksasa". Danau Kerinci di sebelah selatan dan 
Gunung Kerinci dengan ketinggian $3805 \mathrm{~m}$ di atas permukaan laut di sebelah utara dan lereng lembah yang landai merupakan hamparan perbukitan kecil. Di sisi sebelah utara terdapat danau Gunung Tujuh yang merupakan danau tertinggi di Asia Tenggara (BPS Kerinci 2012).

Keunikan lain dari Kabupaten Kerinci adalah merupakan kabupaten yang sekelilingnya berbatasan dengan kawasan konservasi Taman Nasional Kerinci Seblat sehingga tampak seolah-olah Kerinci adalah kawasan enclave terluas. Kabupaten Kerinci memiliki luas wilayah $420.000 \mathrm{Ha}$, di mana lebih sebagian adalah zona ekslusif TNKS (seluas $210.000 \mathrm{Ha}=51,23 \%$ ) sedangkan lebih kurang $49 \%$ merupakan kawasan budidaya kehidupan sosial dan pemukiman masyarakat (Hidayat 2006).

Dusun Baru Lempur adalah salah satu desa yang secara administratif masuk Kecamatan Gunung Raya, merupakan desa penyangga TNKS karena berbatasan langsung dengan kawasan tersebut. Desa Dusun Baru Lempur adalah pemekaran dari Desa Lempur yang populer dengan sebutan Alam Lekuk Limapuluh Tumbi. Tumbi adalah pengembangan dari talang yang merupakan cikal bakal kampung. Tumbi terdiri dari beberapa talang yang anggota keluarganya masih memiliki kekerabatan yang dekat. Pusat pemukiman yang terbentuk dari pengelompokan masyarakat pada suatu talang dalam jumlah tumbi yang lebih besar disebut dengan "koto". Berkembangnya koto secara bertahap akan meningkatkan status koto menjadi "kampung" dan selanjutnya berkembang menjadi sebuah dusun (Gambar 1). Pusat-pusat pemukiman nenek moyang orang Kerinci yang disebut dengan "talang", "koto", "kampung" dan "dusun" ini umumnya berada pada daerah-daerah dataran yang subur di sekitar sungai dan danau.

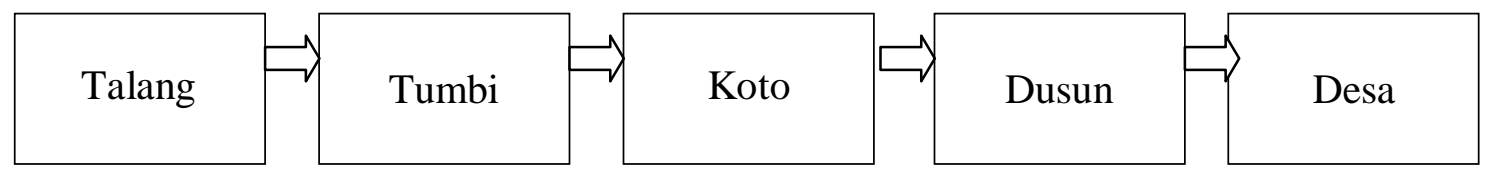

Gambar 1.

Pola perkembangan pemukiman masyarakat Kerinci

Desa Dusun Baru Lempur secara administratif termasuk Kecamatan Gunung Raya berpenduduk 1013 jiwa terdiri dari 492 jiwa laki-laki dan 521 jiwa perempuan ( $320 \mathrm{KK}$ ) berbatasan sebelah utara dengan Desa Lempur Mudik, sebelah selatan dan barat dengan kawasan TNKS sedangkan sebelah timur dengan Desa Manjunto. Desa Dusun Baru Lempur terdiri dari 4 dusun yaitu Dusun Tebing Tinggi, Dusun Alay Sakti, Dusun Sungai Jernih dan Dusun Muara Langkap.

\section{Upacara tradisional kenduri sko}

Kenduri sko adalah upacara adat paling besar bagi masyarakat Kerinci termasuk bagi masyarakat Desa Dusun Baru Lempur, karena melibatkan penduduk seisi kampung. Pesta kenduri sko menggambarkan adanya keterpaduan, keakraban, kesadaran, kebersamaan dan keterbukaan antara sesama anggota masyarakat dan antara anggota masyarakat dengan pemimpinnya sebagaimana falsafah nagari Kerinci. Keterpaduan merupakan satu hal yang diperlukan dalam membangun nagari, kerjasama yang terpadu antara pemimpin dengan rakyatnya, melambangkan musyawarah-mufakat, sebagaimana tertuang dalam pantun adat: memasak nasi dalam periuk, menggoreng dalam kuali. tegak berunding duduk bainok, alamat usaha akan menjadi.

Keakraban diperlukan di tengah-tengah masyarakat, sehingga melahirkan persatuan dan kesatuan, bersatu anggota masyarakatnya dan bersatu dalam tekadnya. Kalau ini sudah dilaksanakan dengan sebaik-baiknya tidak ada kesulitan dalam usaha apa saja; bulat nan seguling, picak nan selayang, tak ada berat yang tak dapat dipikul, tak ada ringan yang tak dapat dijunjung. Kenduri sko dapat menumbuhkan keakraban antara sesama anggota masyarakat, anggota masyarakat dengan para pemimpinnya dan masyarakat kampung lain. Sebagaimana tertuang dalam pantun adat: ijuk jadikan sapu, ambil buluh jadi pelupuh, bersatu kita padu, bercerai kita rubuh. 
Kesadaran untuk melakukan pembangunan manusia seutuhnya, membangun fisik dan mental, kepala diisi dengan ilmu pengetahuan, dada dipenuhi dengan iman dan taqwa sehingga melahirkan kesadaran yang tinggi, menimbulkan kejujuran yang mantap. Kesadaran untuk menjaga kejujuran akan menimbulkan kerjasama yang baik. Perhelatan kenduri sko melatih orang untuk menjadi jujur. Karena diyakini oleh masyarakat bahwa orang yang tidak jujur akan mendapat 'teguran' dari orang gunung (=kemasukan arwah).

Perhelatan kenduri sko merupakan rangkaian kegiatan yang memiliki tujuan antara lain: 1). Pengukuhan dan penobatan orang adat seperti depati, hulubalang, rio dan ninik mamak sebagai pengganti pemangku adat yang telah berhenti sesuai dengan ketentuan adat, 2). Pembersihan dan penurunan benda-benda pusaka adat untuk dapat dilihat oleh masyarakat kampung, 3). Mengikat dan menjalin silaturahim, persatuan dan kesatuan antara masyarakat dalam satu kampung dengan masyarakat dari kampung lain; 4). Pembacaan naskah asal-usul yang dinobatkan dan warga setempat agar warga tahu terutama kaum muda dari mana mereka berasal dan 5). Memohon keselamatan kepada Tuhan Yang Maha Esa, juga kepada roh nenek moyang, roh 'orang gunung' agar diberi rezeki yang melimpah karena setelah kegiatan kenduri sko penduduk akan kembali bersawah dan berladang.

Depati merupakan gelar adat tertinggi dalam satu wilayah yang disebut 'parit bersudut empat'. Seorang depati haruslah yang memiliki 'simbai ekornya, tajam tajinya dan nyaring kokoknya'. Artinya seorang depati adalah orang yang memiliki keberanian untuk berkata benar, berwibawa dan berwatak kepemimpinan. Nyaring kokok-nya berarti pandai berkata-kata, berpengaruh dan sanggup mengatasi massa, tahu ireng jo gendeng, tahu tahan yang menimpa, tahu diranting yang melecut arif bijaksana

Depati dipilih dari seseorang yang ada warisnya, menurut adat disebut 'berkubur berpendam, bertampang berturai, adat bersendi alur, alur bersendi patut, patut bersendi dengan benar'. Pengaruh depati sangat tertanam di dalam masyarakat dusun, 'pusat jala tumpuan ikan' mempunyai fungsi yang besar sekali menghukum, mendenda, melarik, menjaga, mengajum, mengarah menghela membentang dan memelihara baik buruknya anak kemenakan di dusun serta kemajuan pembangunan dusun. Di bawah depati ada ninik mamak (permenti) yang terdiri dari rio, datuk dan pemangku. Ninik mamak mempunyai kekuasaan dalam segala masalah kehidupan masyarakat adat yang bertugas 'keruh dijernih, kusut diselesaikan, rantau jauh dijelang, rantau dekat dikadano (dilayani)'.

Pada awalnya perhelatan kenduri sko adalah upacara adat yang rutin dilakukan setiap tahunnya, waktu pelaksanaannya adalah sehabis masa panen raya. Namun seiring berjalannya waktu dan kebutuhan masyarakat yang semakin meningkat perhelatan kenduri sko mengalami perubahan waktu pelaksanaan menjadi 5 tahun sekali. Sesuai dengan ungkapan adat yang mengatakan 'kerbau seekor dan beras seratus' yang harus dihabiskan untuk upacara ini yang tentu sulit untuk diusahakan oleh masyarakat.

Upacara kenduri sko terdiri dari serangkaian proses kegiatan yang dimulai dengan rapat adat nagari, malam kesenian, penobatan orang adat dan pembacaan naskah asal-usul serta pembersihan bendabenda pusaka. Berdasarkan pengamatan di lapangan, rapat adat dihadiri oleh tokoh adat, alim ulama dan cerdik pandai yang dikenal dengan sebutan tigo tungku sajarangan serta anggota masyarakat. Rapat bertujuan untuk musyawarah memilih siapa yang harus diberi gelar, membicarakan permasalahan-permasalahan dalam masyarakat seperti masalah 'duobuku', masalah kenakalan remaja pantang adat yang dilanggar, sangsi bagi yang melanggar dan membuat kesepakatan-kesepakatan baru berkaitan dengan kepentingan masyarakat. Musyawarah memilih anggota masyarakat yang akan menyandang gelar adat dengan terlebih dahulu meneliti siapa orang tua yang sudah meninggal dunia atau belum meninggal tapi harus diberhentikan karena sudah berusia lanjut dan uzur. Musyawarah juga membicarakan kapan waktu pelaksanaan, bagaimana cara mencari biaya serta pembentukan panitia pelaksana perhelatan.

Masalah 'duo-buku' adalah permasalahan yang dihadapi oleh sebagian anggota masyarakat terkait dengan masalah administrasi pemerintahan dan administrasi secara adat. Sejak diberlakukannya 
Undang-undang Nomor 5 tahun 1979 tentang pemerintahan desa yang menyebabkan terjadinya penyeragaman bentuk desa di seluruh Indonesia secara berangsur-angsur bentuk "kampung" yang dulu ada di Kabupaten Kerinci mulai hilang. Sementara ikatan menurut kekeluargaan adat masih berlaku sehingga dalam menjalankan hak dan kewajiban sebagai anggota masyarakat seringkali tumpang tindih.

Sebelum malam kesenian, dilakukan penurunan benda-benda pusaka. Benda-benda pusaka ini disimpan di dalam sebuah peti dan diletakan di atas ptaih yaitu suatu tempat khusus di atas loteng berupa ruangan kecil yang disangkut ke bubungan sehingga tampak seperti kamar kecil yang tergantung. Cara penurunan benda-benda pusaka ini adalah dengan menyediakan sajian berupa nasi putih, telur ayam, nasi kuning dan hitam, air limau, perasapan dan lain-lain. Pada hari yang ditentukan, berkumpullah orang yang berkepentingan di rumah itu. orang yang ditunjuk itu dikawal oleh anak laki-laki untuk naik ke atas loteng yang diiringi dengan asap kemenyan bau-bauan dari bunga sajian. Peti diambil dan dibawa dengan hati-hati sampai ke pintu loteng yang disambut oleh ketua adat atau orang yang dianggap penting di lurahnya. Penurunan dari atas loteng ke bawah (ke luar rumah) disambut dengan oleh ketua adat atau orang yang dianggap penting di kampungnya. Penurunan dari atas loteng ke bawah (keluar rumah) disambut dengan tari iyo-iyo oleh kaum perempuan, sambil yang lain menebarkan beras kunyit.

Setelah benda itu dibersihkan dan diperlihatkan kepada orang yang hadir, kemudian dimasukkan kembali ke dalam peti. Apabila hari itu dilakukan penobatan gelar adat, maka benda-benda pusaka tadi dibawa ke tempat penobatan untuk dipertontonkan kepada masyarakat. Jika penobatan sudah selesai, maka benda-benda itu dimasukkan kembali ke dalam peti dan dikunci, kunci peti dipegang oleh ninik mamak si pemilik rumah.

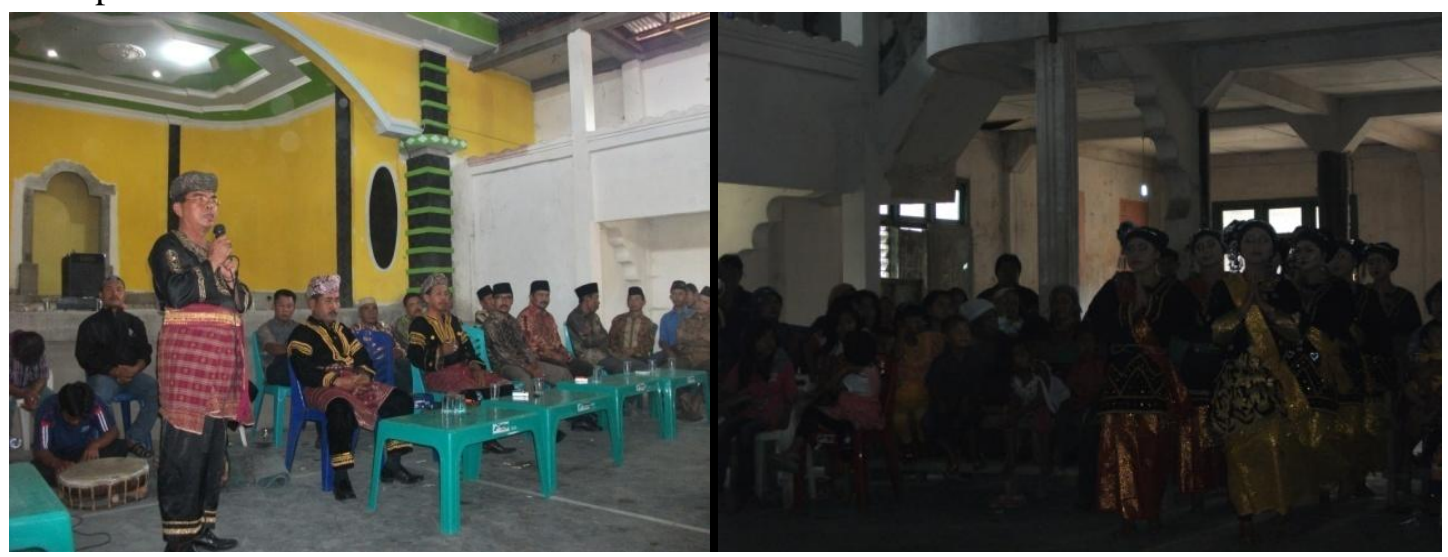

Gambar 2.

Suasana penobatan gelar adat dan tarian iyo-iyo

Setelah acara penobatan gelar adat, malam harinya digelar acara hiburan-kesenian. Awalnya dulu, hiburan pada malam kesenian adalah berupa nyanyian daerah Kerinci diiringi rebab dan gendang, namun kemudian berubah dengan organ dan alat kesenian modern. Menjelang tengah malam, pukul 24.00 waktu setempat dilakukan 'pemanggilan roh-roh orang gunung' melalui ritual adat yang dipimpin oleh tokoh adat berupa nyanyian dan tarian. Tarian yang mengiringi pemanggilan tersebut adalah 'tari tauah' (=tari tauh) yang ditarikan oleh semua anggota masyarakat yang hadir terutama kaum muda-mudi. Tauh berasal dari kata tauhid yang artinya esa, Tari Tauh digunakan untuk menghormati mereka yang dikukuhkan sebagai orang adat dan memuliakan tamu-tamu yang datang. Tale pengiring tari ini disebut mantau, sedangkan instrument pengiringnya disebut dap sejenis rebana dan sebuah gong. Dalam 'pemanggilan orang gunung' tersebut banyak penari yang sampai hilang kesadaran. Tidak hanya penari, penonton pun ada yang kehilangan kesadaran. Kejadian ini diyakini oleh masyarakat bahwa yang tidak sadarkan diri ini 'dimasuki arwah orang gunung'. 


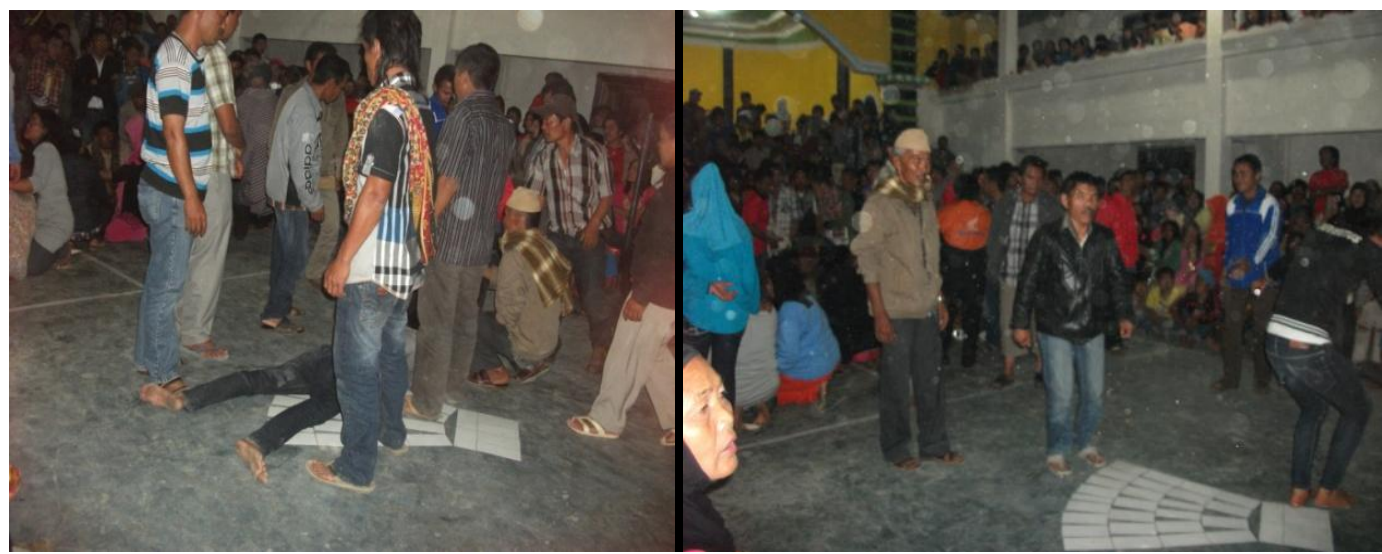

Gambar 3.

Suasana malam kesenian kenduri sko pemanggilan orang gunung di Dusun Baru Lempur

Berdasarkan informasi dari lapangan menyebutkan bahwa 'kenduri sko' ini merupakan wujud syukur masyarakat atas panen yang melimpah dengan berbagi kepada sesama warga dan juga berbagi kepada 'penjaga alam' dan berharap untuk keberhasilan panen pada tahun berikutnya. Seluruh anggota masyarakat menyiapkan hidangan untuk yang berkunjung ke rumah baik dari satu dusun atau orang yang datang dari dusun lain. Makanan khas, yang selalu tersedia saat kenduri sko berlangsung adalah lemang. Lemang dapat dibuat dengan menggunakan talang bambu dan ada juga yang menggunakan tumbuhan kantong semar (Nephentes $s p$ ) sebagai wadahnya, yang mereka sebut dengan 'kancung beruk' (Gambar 4).
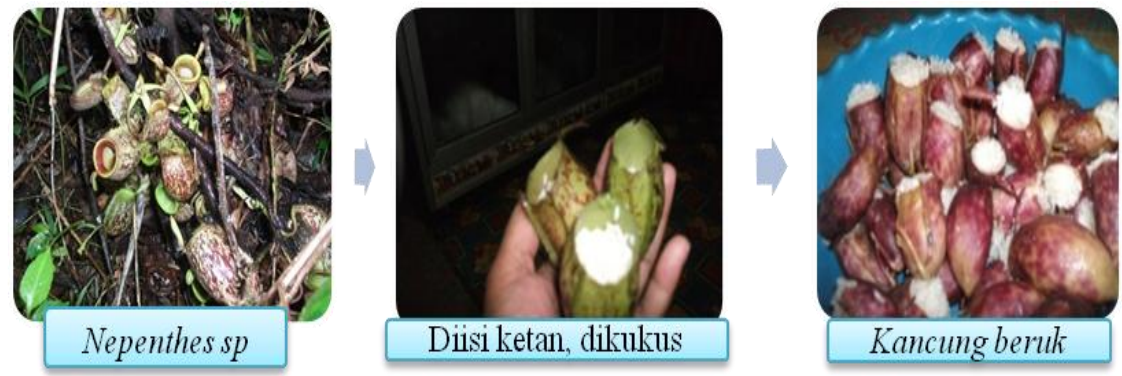

Gambar 4.

Kancung beruk makanan khas saat kenduri sko

Penggunaan kantong semar sebagai pembungkus dilakukan pada saat-saat tertentu seperti upacara adat 'kenduri sko'. Pemungutan kantong semar dilakukan di dalam hutan dengan tidak memungut yang masih muda dan dilakukan dengan menggunakan parang atau gunting pada saat mengambilnya. Hal ini dimaksudkan agar kantong semar yang masih muda masih bisa tetap tumbuh dan berkembang sedangkan penggunaan gunting atau parang dimaksudkan agar guncangan saat mengambil tidak memberi efek stress pada bunga yang tidak diambil sehingga masih bisa tumbuh dengan baik.

Aroma dan rasa yang diberikan dari kantong semar membuat jenis makanan ini disukai. Hasil penelitian menunjukan bahwa kantong semar mengandung enzim protease (Morgan 1996) yang dapat menambah nikmat pada 'kancung beruk'. Kantong semar merupakan tumbuhan tropis yang dapat menjadi indikator iklim, memiliki banyak manfaat antara lain sebagai tanaman hias, cairan yang ada di dalam kantong tertutup dapat digunakan sebagai obat batuk, air rebusan akar dan cairan dalam kantong juga berguna sebagai obat sakit perut. Eksploitasi Nephentes menyebabkan keberadaannya di alam semakin sedikit sehingga termasuk tumbuhan yang dilindungi menurut undang-undang.

Acara perhelatan diakhiri dengan makan bersama yang dilakukan di balai kampung Dusun Baru Lempur, para pemimpin dan anggota masyarakat yang dipimpin makan secara bersama-sama yang disebut dengan makan bajamba (Gambar 5). 


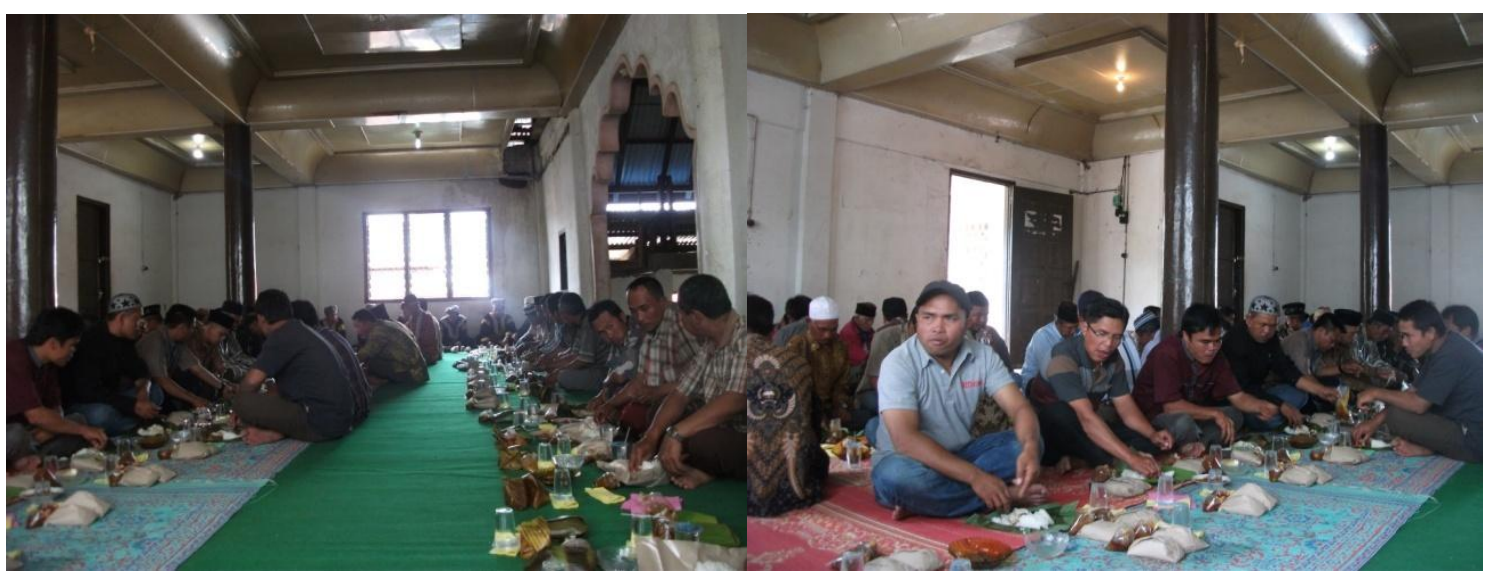

Gambar 5.

Suasana makan bersama di balai kampung Dusun Baru Lempur

Dalam acara makan bersama ini, semua anggota masyarakat membawa makanan dan minuman yang kemudian dibagikan kepada semua tamu yang datang dengan cara bertukar satu sama lain. Makan bersama saat ini telah mengalami perubahan, dulu mereka melakukan makan bajamba dengan menggunakan nampan yang besar kemudian diisi dengan nasi beserta lauk pauknya cukup untuk 8-10 orang, sekarang sudah berubah dengan menggunakan nasi bungkus yang dibagikan kepada masingmasing orang. Makan bajamba dimaksudkan untuk menambah keakraban dan kedekatan silaturahmi sesama warga.

Kenduri sko sebagai kebudayaan bagi masyarakat Kerinci yang secara turun temurun sudah diwariskan telah mengalami perubahan makna. Beberapa perubahan dapat dilihat dari waktu pelaksanaan, rangkaian acara dan bentuk kegiatan. Pelaksanaan helat yang biasanya diadakan tiap tahun setelah musim panen dan menjadi tanda untuk turun kembali ke sawah dan ladang berangsurangsur dikurangi menjadi satu kali dalam 5 tahun. Malam kesenian yang pada awalnya menampilkan nyanyian dan tarian khas Kerinci seperti tari iyo-iyo, tari rangguk dan kesenian bela diri pencak silat digantikan oleh musik dan lagu modern.

\section{Kenduri sko sebuah pesan kebudayaan}

Pesan kebudayaan yang terkandung dalam upacara kenduri sko terdiri dari konsep-konsep dasar yang mengatur persepsi, ingatan, pengalaman dan cara-cara penyampaiannya. Konsep-konsep ini sudah ada sebelum persepsi dan berisikan hal-hal yang berhubungan dengan waktu, ruang, angka dan realitas penyebab. Kebudayaan kenduri sko memiliki representasi mengenai alam semesta yang melibatkan konotasi spasial. Penting untuk mengerti mengenai sistem orientasi dan representasi spasial agar dapat dipahami dampak kenduri sko terhadap perubahan tata ruang. Ruang adalah sebuah gagasan relatif yang secara tak langsung mengatakan tentang sebuah titik dalam kaitannya dengan titik yang lain. Pandangan seseorang terhadap ruang mempengaruhi pandangan orang tersebut mengenai kejadian di masa lampau.

Representasi terhadap alam semesta ditunjukan oleh keyakinan akan adanya 'orang gunung' yang datang dari pegunungan sekitar untuk menikmati malam kegembiraan bersama warga. Hal ini menunjukkan bahwa masyarakat Kerinci memiliki pengetahuan dan kepercayaan terhadap alam semesta yang memiliki fungsinya masing-masing. Masyarakat meyakini bahwa gunung adalah tempat sakral, tempat arwah para leluhur berdiam sehingga gunung harus dihormati dijaga dari kerusakan. Vansina (1985) menyatakan bahwa konsep alam semesta tidak hanya melibatkan bumi, ia juga melibatkan langit seperti halnya suku Ainu dari Sakhalin. Suku ini membagi alam semesta ke dalam garis horizontal dan garis vertikal, bumi dibagi menjadi tempat yang lebih duniawi dan tempat yang lebih sakral. Waktu sebagai suatu konsep kebudayaan memiliki banyak karakteristik yang sama dengan ruang. Waktu adalah masa bagi seseorang untuk berkelana dalam ruang yang tercipta. Arah 
waktu dikaitkan dengan persepsi terhadap norma, lebih baik atau lebih buruk, masa keemasan ada di depan kita ataukah sudah lama berlalu. Konsep waktu kenduri sko menunjukan bahwa pelaksanaan kenduri sko dari waktu ke waktu mengalami perubahan yang disebabkan oleh adanya faktor internal dan faktor eksternal. Faktor internal antara lain berkurangnya peran dan tanggung jawab para tokoh adat, benda pusaka berumur sangat tua sehingga dalam penurunan benda pusaka tidak bisa dilaksanakan lagi, pertambahan dan pertumbuhan penduduk mempengaruhi tingkat perekonomian masyarakat sehingga 'kerbau seekor dan beras seratus' sulit untuk memenuhinya. Faktor eksternal dapat berupa pengaruh pendatang sehingga mempengaruhi sistem nilai yang dianut masyarakat Kerinci.

Konsepsi terhadap waktu secara umum dapat berupa sebuah kekekalan, waktu berupa siklus dan waktu berupa garis linear, tetapi tidak ada kebudayaan yang hanya menggunakan satu dari representasi ini. Para ahli membagi tiga jenis waktu yaitu masa penciptaan yang ada di luar waktu, waktu siklus (yang menyangkal hubungan sebab akibat dalam masa lalu) serta waktu linear (yang memiliki hubungan sebab akibat dengan masa lalu yang baru saja berlalu). Waktu sebagai sebuah kekekalan mempertahankan pendapat adanya gagasan tentang keabadian dan penciptaan, sedangkan waktu siklus dan linear hidup berdampingan dalam sebuah konsep durasi yang tunggal.

Berdasarkan hasil pengamatan dan informasi di lapangan menunjukan bahwa kenduri sko memiliki konsep waktu berupa siklus dan garis linear yaitu waktu berjalan ke arah sebuah akhir menjadi sebuah kekekalan yang hidup berdampingan. Perubahan yang terjadi dalam pelaksanaan kenduri sko menunjukan perubahan yang menuju kepada suatu akhir, apakah kenduri sko masih akan tetap ada atau berakhir? Pengertian kualitatif mengenai waktu beragam dari satu kebudayaan dengan kebudayaan lainnya dan harus dinyatakan secara terpisah dalam setiap kasus, lebih lagi karena konsep mengenai waktu sangat penting dalam memahami tradisi.

Kenduri sko harus disampaikan dan diwariskan kepada generasi mudanya sehingga menjadi suatu kebenaran sejarah. Dalam banyak kebudayaan, kebenaran adalah suatu hal yang terus menerus diulangi dan yang sudah dinyatakan sebagai hal yang benar oleh nenek moyang. Tetapi terkadang kebenaran tidak mencakup suatu gagasan $x$ ataupun $y$ saja, pada saat seseorang mendengar pernyataan yang bertentangan dengan kepercayaan sehari-hari mereka dari nenek moyang, walaupun benar tidak mudah untuk meyakininya kecuali dengan melihat secara nyata karena apabila tidak demikian maka tradisi adalah benar tetapi tidak faktual. Oleh karena itu kenduri sko adalah menjadi suatu kebenaran sejarah bagi kebudayaan masyarakat Kerinci.

Sebagai sebuah kebenaran sejarah, kenduri sko adalah sebuah kausalitas sejarah dan perubahan. Kausalitas sejarah merupakan hubungan antara fenomena seiring waktu. Kejadian atau situasi masa lampau menyebabkan kejadian atau situasi di masa berikutnya. Kausalitas dianggap sebagai sesuatu hal yang terus bekerja, bahwa hal-hal selalu berubah, tidak ada hal yang tetap sama seiring perjalanan waktu bahkan pada saat kelihatannya ia tidak berubah. Namun demikian, masyarakat berkebudayaan lisan seperti kebudayaan kenduri sko ini cendrung memiliki gagasan yang lebih sederhana mengenai kausalitas sejarah, satu gagasan yang sama sekali meniadakan perubahan secara berkala.

Ciri lain dari bentuk kausalitas masyarakat berkebudayaan lisan seperti kenduri sko ini adalah bahwa manusia memiliki tanggung jawab untuk perubahan. Masyarakat menciptakan teknik-teknik, institusi dan kegiatan baru sehingga kebudayaan itu menjadi rangkaian sejarah para tokoh kebudayaan yang melahirkan perubahan tersebut. Mereka bertanggung jawab untuk berbagai penemuan sehingga tokohtokoh di zaman berikutnya tidak pernah merubah penemuan oleh generasi pendahulunya, mereka hanya menambahkannya. Dalam pandangan ini masa kini hanyalah sebuah perubahan tambahan terhadap masa lalu. Kausalitas sebagai sebuah proses perubahan tidak ditemui pada masyarakat berkebudayaan lisan. 


\section{Simpulan}

Kenduri sko merupakan tradisi lisan masyarakat Kerinci yang telah berlangsung sejak lama dan turun temurun diwariskan dari generasi masa lalu kepada generasi masa kini. Sebagai suatu tradisi lisan, kenduri sko memiliki peran dalam penyusunan ulang kejadian masa lalu yang merupakan pesan dari masa lalu ke masa kini. Kenduri sko memiliki pesan-pesan kebudayaan yang merupakan representasi dari ruang, waktu, kebenaran sejarah dan kausalitas perubahan. Kenduri sko memiliki makna keterpaduan, keakraban, kesadaran, kebersamaan dan keterbukaan yang menjadi pokok-pokok pembangunan dalam nagari Kerinci. Representasi dari ruang dinyatakan oleh keyakinan akan adanya alam semesta (bumi dan langit) dengan fungsinya masing-masing, representasi waktu ditunjukan oleh keyakinan terhadap waktu sebagai masa untuk berkelana mencari kebaikan dan perubahan. Kenduri sko sebagai pesan kebenaran sejarah dan kausalitas menunjukan adanya perubahan yang terjadi akibat dari hukum sebab akibat dalam lintasan waktu yang bersifat siklus dan linear sehingga menuju kepada suatu kekekalan yang tidak akan berubah lagi.

\section{Daftar Pustaka}

Aumeeruddy Y \& Sansonnens (1994) Shifting from simple to complex agroforestry systems: An example for buffer zone management from Kerinci (Sumatra, Indonesia). Agroforestry Systems 28: 113-141.

Biro Pusat Statistik (2012) Kerinci dalam angka. Kabupaten Kerinci.

Creswell JW (2009) Research design qualitative, quantitative and mixed methods approaches.

Hidayat H (2006) Perspeksi stakeholders dalam pengelolaan Taman Nasional Kerinci Seblat di era otonomi daerah. Jurnal Masyarakat Indonesia Jilid XXXII No 1 Tahun 2006. LIPI.

Neuman WL (2006) Social research methods qualitative and quantitative approaches. Sixth Edition. University of Wisconsin at Whitewater.

Irawan P (2006) Penelitian kualitatif dan kuantitatif untuk ilmu-ilmu sosial. Jakarta: Departemen Ilmu administrasi Fakultas Ilmu Sosial dan Ilmu Politik Universitas Indonesia.

Undang-Undang Republik Indonesia No 5 Tahun 1979 tentang Pemerintahan Desa.

Vansina J (1985) Oral traditional as history. Madison University of Wisconsin Press. tradisi lisan sebagai sejarah (2014) Terjemahan Astrid Reza dkk. Yogyakarta: Penerbit Ombak.

Yakin R (1986) Menggali adat lama pusaka usang di Sakti Alam Kerinci. Tidak dipublikasikan.

Zakaria I, Swastiwi AW dan Swarta A (2012) Sejarah etnis di Kabupaten Kerinci Provinsi Jambi. Balai Pelestarian Nilai Budaya Tanjung Pinang. Tidak dipublikasikan. 